\title{
Hubungan Kerja Virtual
}

\author{
Fuat Edi Kurniawan - detikNews
}

Transformasi digital secara luas bukan hanya menciptakan pola-pola baru dalam produksi, distribusi, dan konsumsi, tapi juga berimplikasi pada kekuasaan. Dalam hal ini, struktur sosial masyarakat dapat berubah seiring dengan perubahan aset dan modal yang bergerak secara lentur dan cepat pada masyarakat informasi pada saat ini.

Pemerintah terutama di negara-negara berkembang bahkan mengalami kegagapan dalam melihat perkembangan digital. Pada umumnya mereka tidak tanggap atas perkembangan yang terjadi, seperti tidak memiliki regulasi yang jelas dalam mengatur perkembangan digital, goncangan industri manufaktur seperti efisiensi tenaga kerja dan PHK juga tidak disikapi dengan jelas. Hal ini menjadikan tantangan dan kontradiksi yang diajukan ke pasar tenaga kerja melalui digitalisasi. Tantangan ini dilihat dari sudut yang berbeda, seperti kehilangan pekerjaan, polarisasi pekerjaan dan ketidakamanan pendapatan, dan dampak negatif lainnya.

Berbagai persoalan yang tidak ditanggapi secara matang oleh pembuat kebijakan antara lain mengenai perubahan sosial yang menyangkut aset, modal, dan kekuasaan, sehingga seolah telah membiarkan relasi kerja baru yang tercipta dalam ekonomi digital yang berkembang secara cepat itu menjadi rapuh, terutama bagi pekerja.

Kemunculan berbagai platform digital yang pada dasarnya telah membuka peluang kerja baru pada aspek informal, pada sisi lain pemilik modal justru mengaburkan hak-hak pekerja. Sebab hubungan kerja yang terbentuk hanyalah berbasis "virtual agreement". Klausul yang disepakati dalam perjanjian virtual tersebut jauh dari skema perjanjian kerja yang memberikan perlindungan bagi pekerja.

Permasalahan ini juga memperlihatkan bagaimana Revolusi Industri 4.0 menciptakan banyak platform digital yang melahirkan bentuk eksploitasi gaya baru dan menunjukkan posisi utopis dari keberadaan teknologi digital dan internet. Industri 4.0 telah mengarah pada polarisasi yang terus berkembang antara pekerja tidak tetap dengan elit kaya dan menunjukkan bagaimana kekuatan kelas tidak dapat dipisahkan terkait dengan komputerisasi.

Analisis pengambilan keuntungan didasarkan pada eksploitasi manusia, baik dalam pembuatan perangkat digital dan dalam praktik tenaga kerja digital. Tenaga kerja ini sama halnya di sektor informal, yang dibentuk oleh kontrak kerja yang tidak jelas, tidak terjadi proses kerja dan tawar-menawar upah. Tenaga kerja sektor informal ini tidak memiliki posisi tawar yang kuat. Sehingga posisi tenaga kerja menjadi inferior dan cenderung tereksploitasi secara sistemik.

Relasi kemitraan yang terjalin antara pelaku usaha/industri dengan pekerja juga memunculkan anomali baru. Relasi ini mengaburkan hak dan perlindungan tenaga kerja yang telah menegasikan jaminan sosial tenaga kerja, jaminan kesehatan, jaminan kecelakaan kerja, jaminan hari tua, dan sebagainya. Pada dasarnya jaminan ini sudah menjadi tanggung jawab bagi pelaku usaha untuk melindungi tenaga 
kerjanya. Mereka yang bekerja pada sektor informal seperti UMKM berbasis digital atau transportasi ojek berbasis online, secara tidak disadari telah mengalami eksploitasi.

Eksploitasi gaya baru di era digital ini menjadi masif setelah kemunculan berbagai platform digital. Relasi ekonomi yang diciptakan melalui berbagai platform ini merupakan bentuk eksploitasi gaya baru yang dimunculkan melalui permainan yang membuat para pekerja mengalami ketergantungan di tengah situasi rapuh yang dibiarkan tanpa regulasi yang mengatur hubungan kerja keduanya.

Pelaku usaha dan penyedia aplikasi platform digital menutupi praktik eksploitasi tenaga kerja dalam bingkai retorika kebebasan, fleksibilitas, dan kemitraan. Perusahaanlah yang berada di puncak kekuasaan, dengan kontrol pada teknologi, modal, dan akses. Dalam konteks ini, dapat kita pahami bahwa permasalahan yang dihadapi Indonesia di era digitalisasi adalah soal penentuan konsep teknologi dan masyarakat komunikasi macam apa yang akan dibangun.

Perkembangan teknologi dan industri di era digital memang harus dilihat secara paralel dengan proses industri dengan logika internal yang menyertainya. Tetapi, tetap saja teknologi dan industri digital harus dilihat secara kritis. Artinya, proses perkembangan digitalisasi seharusnya tidak mengalienasikan pekerja dari struktur yang lebih besar atau bahkan mereduksi manusia ke dalam residu teknologistik belaka.

Perkembangan digital seharusnya bisa dimanfaatkan dalam mempengaruhi transformasi sosial yang membangun optimisme industri, teknologi, dan memberdayakan masyarakat secara lebih luas. Kewenangan negara dan kekuatan swasta perlu diintegrasikan untuk bertindak dan bertanggung jawab secara sosial. Sehingga transformasi digital pada saat ini mampu menemukan dan menciptakan ekonomi baru sebagai perluasan lapangan kerja dan akses informasi yang lebih luas.

Perkembangan teknologi digital juga didorong untuk bisa menciptakan adopsi inovasi yang meliputi pemanfaatan komparatif praktik hidup, kompatibilitas nilai dengan kebutuhan masyarakat, kesederhanaan pemakaian, dan memberikan manfaat bagi berbagai unsur masyarakat.

Fuat Edi Kurniawan peneliti di Pusat Penelitian Kependudukan LIPI 